\title{
Wastewater Management to Conservation and Its Coping to Climate Change Impacts
}

Kristiyanto $^{12}$

${ }^{1}$ Indraprasta PGRI University, TB. Simatupang, Jl. Nangka Raya No.58 C, Jagakarsa, South Jakarta, 12530, Indonesia

${ }^{2}$ Department of Biology, Faculty of Science and Technology, State Islamic University Syarif Hidayatullah Jakarta. Jl. Ir. H. Djuanda No. 95, Ciputat, South Tangerang 15412, Banten, Indonesia

*Corresponding author: kristiyanto94@gmail.com

Abstract: The drought is one of all phenomena at local to a global scale that caused climate change impacts, alongside it also the human activities related, which were deforested and land use changed that caused to ecological disturbance, which one is hydrological changes. Hence, it's a lot of lost productivity, chiefly to farming land aspects and the other, so the land restoration by reforestation is needed in framework to water cycle (hydrology) process kindly. The aim of this research has identified and analyzed ecological restoration to ecosystem services, chiefly in wastewater management (treatment) to conservation, especially in Al Zaytun areas (Pesantren), so observing and in-depth individual interview (with some of personage and pesantren of boards) is one method that used to data collected, alongside land survey management to classified type development in Al Zaytun areas. The result of this research revealed that Al Zaytun successfully in water management to conservation by wastewater treated management by Eichhornia crassipes (Enceng gondok), afterward to the reservoir as water saved development. Those conservation types considered capability in reviving to ecological systems to ecosystem services increased kindly, alongside to land restoration by some of the plant species or trees to grow and developed in which Tectona grandis L. f is more dominantly and it's favorite because of investment economic that advantage based on ecological perspective. These were type management that did by Al Zaytun, alongside its able in coping to both drought and climate change impacts kindly and adaptively, and of course, it's part of an obligation as the follower's Islam religion in preserving and maintaining natural resources, chiefly to water resources.

Keywords: Al Zaytun, Climate change, Drought, Islamic perspective, Plant species, Reservoir

\section{Introduction}

Maintaining and preserving water resources conservatively, kindly, and sustain is one obligation to all human, especially to Islamic' follower of religion (Umat Islam) (Amery, 2001), which has revealed in the Holy Qur'an (QS Al A'raf 56-58; QS Ar-Rum 41-42), but the fact has shown a lot of environmental hazards, which one is the drought occurred intensively that annually occurrence at local to a global scale. Climate change impacts are also part of brought to disaster (Andrew and Sauquet, 2017; Ghazali et al. 2018), which one is the health risks, alongside unpredictable season (rainy to dry season), which is lead to drought, flood, and the other in some perspective (Dai et al. 2018; Mukherjee et al. 2018). Hence, according to Hagemann et al. 
(2013) that climate change is a dominant factor in environmental degradation to hazards, which one is hydrological changed (Vetter et al, 2017; Fang et al. 2015), which leads to water shortage, alongside to social conflict interest. On the other hand, the human activities (anthropogenic) to land-use change is also contributed to the loss of the water cycle and its lead to water shortage extremely (water crisis), which is one global issues and its more impaired, alongside its lead to human suffered (Yongsi, N, B, H. 2010)

The drought is also part of land-use change impacts related, so it's not easy to cope in managing environmental hazards kindly, chiefly to water management to conservation. Hence, restoration included to reforestation, alongside waste management, chiefly to water ecologically (treatment), which is one strategy in the water supply (availability or stock) and of course, it leads to environmental health kindly and sustains (Omar et al. 2018). Hence, the water is pivotal in supported to human activities such as irrigated to farmland, industrial, livestock, and so on. Hence, it needed to water availability kindly and freshly, but refers to description previously the freshwater availability would be facing to water shortage. Refers to description formerly (above) that water crisis or shortage is one disaster that caused of human activities impacts (anthropogenic), which has changed to water cycle (hydrological) and water polluted, and of course, it contrasted to the Holy Qur'an, who Allah SWT created to universe included to water resources, mainland resources, energy sources, and the other that must to preserved and maintained it, with fully message. These were all natural resources or potential for human wellbeing, so it's an obligation to manage and utilize it kindly and friendship based on religions of value.

Hence, Reusing water daily has become of purpose in which is part of one strategy in coping to climate change impacts (Andrew and Sauquet, 2017), alongside it would be strengthened to social resilience system kindly or its more adaptively to drought occurrence. Hence, creating and developing to reservoirs at a local scale were able in coping to drought in which has caused climate change impacts related (Heejun Chang and Bonnette, 2016). Reviving to land resources, which one is a forest in where barren has become of fertile to productive is the one step to land conservation and it's also one way to save or rainwater harvesting methods effectively. Al Zaytun areas as the one of all pesantren in Indonesia that ability to wastewater treatment (management) locally and simplify, therefore, in this studies tried to explore and understanding to wastewater treatment developed and its functions to surroundings (ecological perspective), alongside its role in economic development to local people or at the local scale.

\section{Material and Methods}

Surveying or observation and in-depth individual interview methods about the environmental condition at $\mathrm{Al}$ Zaytun is part of one data collection process in the field, which one is both to know and understand to water 
availability (management) that developed (reservoir water) and its functions to around (Al Zaytun areas). Al Zaytun areas administratively included in Indramayu Regency (Figure 1) in where is the one paddy plated and its productivity central in Indonesia state, so the water resources or availability is needed in each plant season, especially to paddy planted. On the other hand, the Indramayu Regency included in the Al Zaytun area has confronted climate change impacts that caused of water shortage, so it leads to drought extremely. Those cases were one problem that confronted farmers in water availability kindly and sustains in their activities. Depending on rainwater is one way that done by the farmers, it's because of rainfed land type in which it needs to water availability in plating to paddy kindly and sustain. Hence, Indramayu Regency is also susceptible to drought occurred, so how to water availability as long as to paddy planted.

On the other hands, pesantren $\mathrm{Al}$ Zaytun tried to reservoir designed and developed in their areas, which one has utilized to wastewater with treatment simplifies or locally to plant species, which one is Eichhornia crassipes (Enceng gondok) that have a function to purification to water quality based on Islamic values (Mokhtar et al. 2015). Hence, this research is more to explore in wastewater management that has done by Al Zaytun at this long time, alongside it various in used to and is part of the adaptation process to climate change impacts, so how far Al Zaytun has preparedness it. The most important in this research would be known to reservoir developed in surroundings, and its impacts or functions in the other (Figure 1). The role of the reservoir to ecosystem functions increased is one analysis in this research, alongside it how to effectively in coping to climate change impacts, chiefly in overcoming unpredictable to season flexibility, kindly, and ecologically in support to their activities as the farmers.

Figure 1 Research of Site

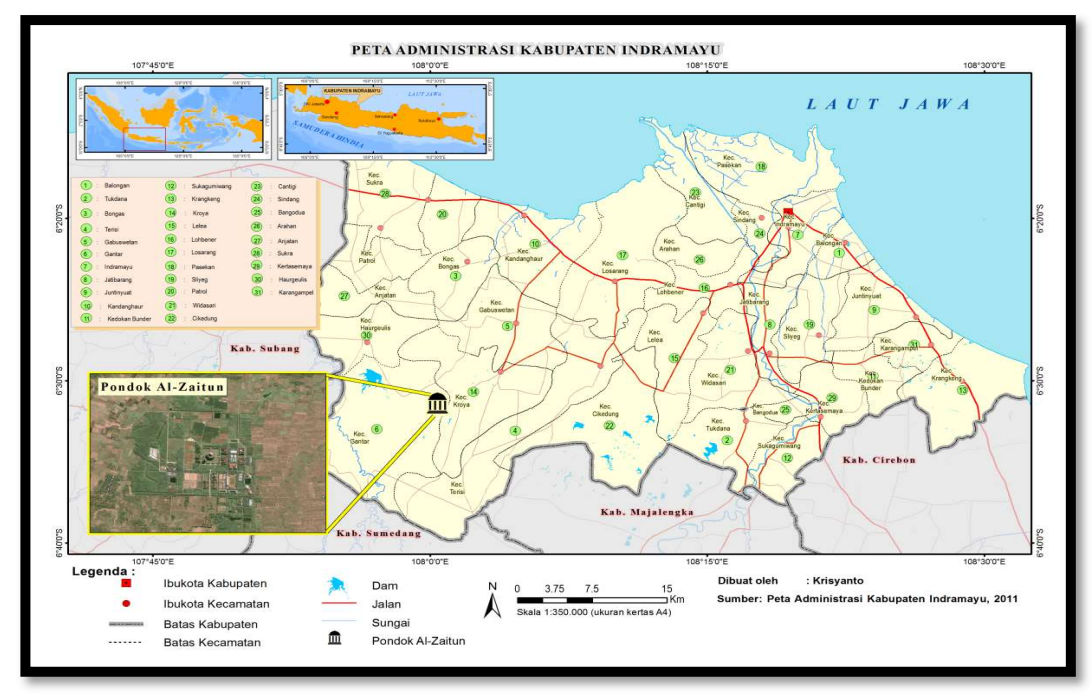

Sources: Doc. Kristiyanto, 2015 


\section{Results}

Al Zaytun is one of all pesantren in Indonesia that ability to adapt or hold out on barren condition kindly, alongside reviving to ecosystem function with water availability (stock) by sustain in framework to wetland or fertile based on wastewater treatment (Plant species). Hence, developing to pesantren based on ecological perspective, chiefly to natural management is pivotal and of course, it would be part of sustainable development in where Al Zaytun has able to actualize it, which wastewater treatment (management) is one paradigm that carries out in their development. Reusing wastewater treatment result is one step or strategy in coping with shortage, and it's part of water conservation, alongside a response to climate change impacts. The water is pivotal and it's needed to supply in farmland, livestock, garden, and so on, so it must be water availability kindly and sustain on supporting it. Those part of purposed of $\mathrm{Al}$ Zaytun as Islamic religion representative in reviving to barren has become of fertile or wetland to productive kindly and optimal.

Hence, reservoir designed and development is the one way in actualizing it, alongside it has become of one source and it would be considered to both adapting and coping to climate change impacts (Mehran, A et al. 2017) effectively, chiefly in confronting to drought occurrence or climate change impacts. Refer to the description above that Al Zaytun has successfully to land modified both to productivity and conservation in which leads to economic stability based on water management, without impaired environmental conditions. This is part of the development ideal and of course, it agreed within the Holy Qur'an.

\section{Discussion}

\section{Reservoir as Ecosystem Services}

Saving or water availability (stock) is the one step to ecosystem services increased in which would be reviving to wetland kindly (Fiona Culhane, 2019). Hence, Reusing with Recycling to water resources with wastewater treatment is part of an alternative solution that able to water availability or supply kindly, sustain, and ecologically, alongside it would be maintained to ecosystem stability (equilibrium) and of course, it leads to ecosystem service increased. The reservoir is also as sources of primary to be alive including to reviving in land management to wetland or fertile (land conservation), so Al Zaytun in their development that the water resources has become of one attention in each their activated, alongside it would be one way in water conservation to food, and energy security goals. 
Figure 2 Reservoir Type Developed in Pesantren Al Zaytun Areas

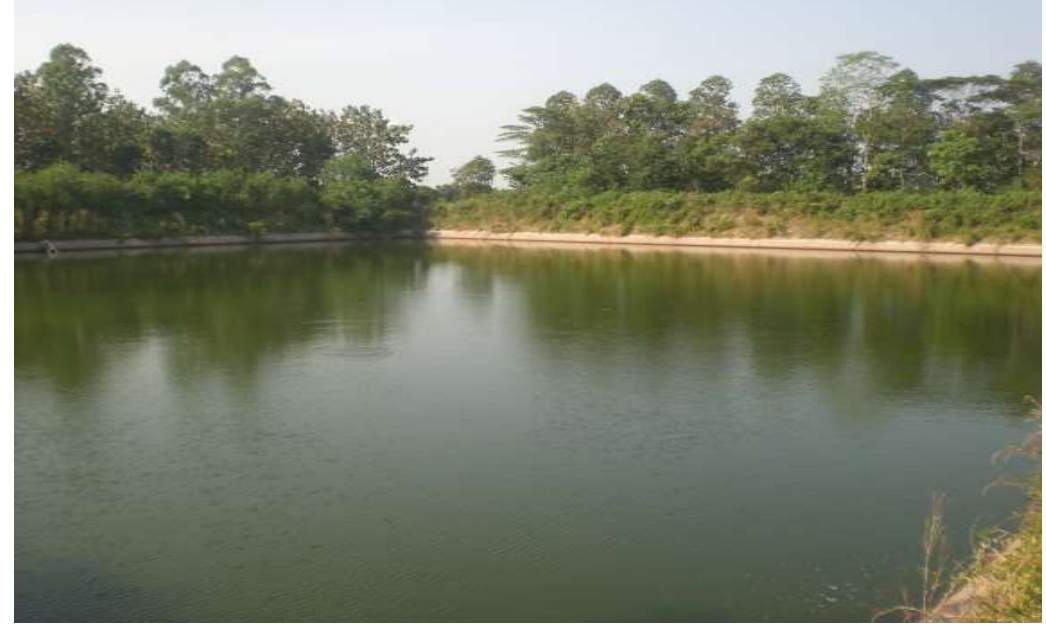

Source: Doc. Kristiyanto, 2015

In Figure 2 above is one example that $\mathrm{Al}$ Zaytun is able to create of alive to the ecosystem in which has become of wetland and of course to greenery shaped in surroundings. These are part of the sustainable development paradigm in which has created and developed by Al Zaytun kindly, alongside it would be influenced to the stability of ecosystems, chiefly in the aquatic ecosystem. Stability of aquatic ecosystem that formed at Al Zaytun, indirectly to ecosystem services increased, alongside it would be rich of water potential to welfare at local to national scales such as aquaculture development, freshwater availability, and aqua-plant development (Fiona Culhane et al. 2019). Hence, the reservoir is a lot of multifunction in surroundings, especially in saving to water (rainwater harvesting) in which would be used to a long time and sustain, and its part of water conservation with a variety of ecosystem functions, alongside it would be biota increased and the other (Grizzetti, B et al. 2019).

\section{Wastewater Management to Recycle and Reuse Development}

Reutilizing water based on wastewater treatment results at local to global scale is part of water conservation, while minimalized to water pollution in modern era impacts (industrial activated), alongside in coping to drought in which caused to climate change impacts (Andrew and Sauquet. 2017). Hence, according to Mngumi (2020) that increasing ecosystem services by wastewater management (treatment) is one step to the resilience of both ecological and social systems kindly, and its part in coping to drought or climate change impacts (Hughes, J et al. 2021).

Reviving to ecosystem services, which one is wastewater (treatment) management development to reservoir developed in actualizing to sustainability, so the water is pivotal or role in daily, especially in supporting to welfare or wellbeing achieved. Hence, there was some way in water 
conservation developed, which one is wastewater treatment in which considered to ability in maintaining to water conservatively and its water quality. The one that is used to plant species for example is Eichhornia crassipes (Mishra and Maiti, 2017) in wastewater treatment to water quality, which one is used to phytoremediation or purification approach or methods in removing water polluted (Ansari et al. 2020; Khadidja and Nadjiba, 2019).

Utilizing plant species (Eichhornia crassipes) as purification function and its process to water quality (freshwater) obtained is part of a step in maintaining to water in which reservoir as water-saving freshly and quality, so it leads to water security based on wastewater management (treatment). Those cases could be shown in Al Zaytun did, where is able to wastewater management kindly in which waste disposal domestic such as wash water or kitchen wastewater (Rijwana and Paul, 2018), bathwater, and so on, alongside to rainwater harvesting that managed conservatively. Those ones are reservoir modified and developed that created and developed in Al Zaytun areas (Figure 1). Refers to description formerly, that reservoir is wastewater treatment process resulted and its simplify technique in the process, which one is used to planting species, for example, is (Eichhornia crassipes).

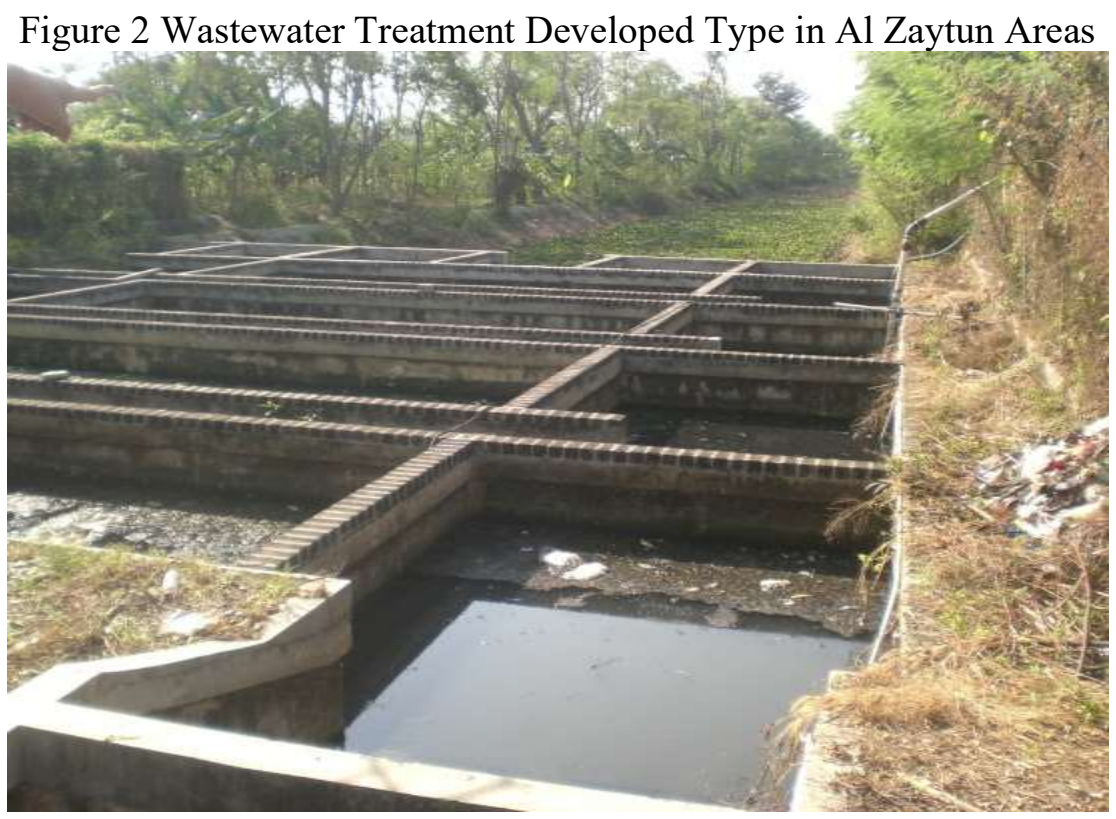

Source: Doc. Kristiyanto, 2015

Eichhornia crassipes (Enceng gondok) is the one plant species that used in wastewater treatment and considered to capable of removal pollutants kindly (Mishra, S and Maiti, 2017; Rezania S et al. 2013), although there were some plant species that able to purification or Re-cycle and it's Re-use. Hence, refers to description formerly that Reutilizing water resource daily based on wastewater treatment resulted is part of the sustainability paradigm, alongside it would be become of representative development in water management with 
utilized to plant species as a photo-purification process to water quality (Khadidja and Nadjiba, 2019).

\section{Conclusions}

Wastewater treatment development is the one way in water management to conservation, alongside its ability to coping with a drought that caused of climate change impacts related. Hence, Al Zaytun tried to reservoir developed in which as water-saving methods and considered to water availability kindly and sustain. The reservoir is part of wastewater treatment resulted by used to plant species in which is Eichhornia crassipes (Enceng gondok). This plant species is able to the purification of wastewater domestic kindly and ecologically to water quality, so it could be reused, alongside as water conservation.

\section{References}

Amery, A, H. Islamic Water Management. International Water Resources Association, 2001, 26 (4), 481-489.

Ansari, A, A, Naem, M, Gill, S, S, Alzubaibr, M, F. Phytoremediation of Contaminated Waters: An Eco-friendly Technology Based on Aquatic Macrophytes Application. Eqyptian Journal of Aquatic Research, 2020, (46), 371-376.

Andrew, T, J, Sauquet, E. Climate Change Impacts and Water Management Adaptation in Two Mediterranean-Climate Watershed: Learning from the Durance and Sacramento Rivers. Water, 2017, 9 (126), 1-24.

Chang, H, Bonnette, R, M. Climate change and water- related ecosystem services: impacts of drought in California, USA. Ecosystem Health and Sustainability, 2 socia 2016, (12), 1-19.

Culhane, F et al. Risk to the supply of ecosystem services across aquatic ecosystems. Science of the Total Environment, 2019, 660, 611-621.

Dai, A, Zhao, T, Chen, J. Climate Change and Drought: a Precipitation and Evaporation Perspective, Current Climate Change Reports, 2018, 1-15.

Fang, $G$ et al. Climate Change Impact on the Hydrology of a Typical Watershed in the Tianshan Mountains. Advance in Meteorology, 2015, (4), 1-10.

Grizzetti, B et al. Relationship between ecological condition and ecosystem services inEuropean rivers, lakes and coastal waters. Science of the Total Environment. 2019, 671, 452-465.

Ghazali, A, D et al. Climate Change Impacts on Disaster and Emergency Medicine Focusing on Mitigation Disruptive Effects: an International Perspective. Int J Environ Res Public Health. 2018, 15 (7), 1379.

Hagemann, $\mathrm{S}$ et al. Climate change impact on available water resources obtained using multiple global climate and hydrology models. Earth Syst. Dynam, 2013, (4), 129-144.

Hughes, $\mathbf{J}$ et al. Impacts and implications of climate change on wastewater systems: A New Zealand perspective. Climate Risk Management, 2021, (31), 1-19.

Khadidja, B, Nadjiba, C. Phyto-Purification of Polluted Water by Using Poaceae Case of Lake Regaia. Pak. J. Bot., 2019, 51 (3), 1-9. 
Mehran, A et al. Compounding Impacts of Human-Induced Water Stress and Climate Change on Water Availability, Scientific REPORTS, 2017, (7), $1-9$.

Mishra, S, Maiti, A. The efficiency of Eichhornia crassipes in the removal of organic and inorganic pollutants from wastewater: a review. Environ Sci Pollut Res, 2017, 16 (1), 1-18.

Mokhtar, I, M, Abdullah, R, Baharuddin, A. An Islamic Perspective on Water Quality: A Case of Malaysia. Water Policy, 2015, (17), 454-471.

Mukherjee, S, Mishra, A, Trenberth, E, K. Climate Change and Drought: a Perspective on Drought Indices. Current Climate Change Reports, 2018, 1-20.

Mngumi, E, L. Ecosystem services potential for climate change resilience in peri-urban areas in Sub-Saharan Africa. Landscape and Ecological Engineering, 2020, (16), 187-198.

Omar, M, S, Chowdhury, K, J, A, Hashi, A, A. Islamic Ethnics Waste Management towards Sustainable Environmental Health. IIUM Medical Journal Malaysia, 2018, 17 (1), 193-197.

Parwin, R, Paul, K, K. Treatment of kitchen wastewater using Eichhornia crassipes. E3S Web of Conferences (CENVIRON) 2018, 34, 02033, 1-5.

Rezania, S, Din, MD, F, M, Ponraj, M, Sairan, Md, F, Kamaruddin, BM F, S. Nutrient uptake and wastewater purification with Water Hyacinth and its effect on plant growth in batch system. Journal of Environmental Treatment Techniques, 2013, 1 (2), 81-85.

Yongsi, N, B, H Suffering for Water, Suffering from Water: Access to Drinking-water and Associated Health Risks in Cameroon. J. Health Popul Nutr, 2010, 28 (5), 424-435.

Evaluation of sources of uncertainty in projected hydrological changes under climate change in 12 large-scale river basins. Climate Change 2017, (141), 419-433. 